\title{
Early against classic extubation outcomes following cardiac surgery and correlation with rapid shallow breath index
}

\section{Kardiyak cerrahi sonrası klasik ekstübasyona karşı erken ekstübasyonun sonuçları ve hızlı-yüzeyel solunum indeksi ile ilişkisi}

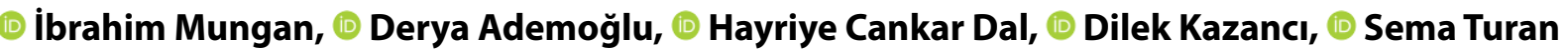

'Intensive Care Unit, Ankara Training and Research City Hospital, Ankara, Turkey

\begin{abstract}
Introduction: Overnight postoperative ventilation following cardiovascular surgery was a routine procedure since 1960 and the usage of high-dose opioid anesthetic techniques strengthens the need. However early extubation of postcardiac patients has been claimed as safer and more cost-effective approach. Rapid shallow breath index (RSBI) is used widely to standardize weaning from Mechanical ventilatory support (MVS) and to predict failure of attempt. The aim of this retrospective study was to determine the impact of early extubation on post-cardiovasular surgery patients and the possible correlations of RSBI values.

Methods: This retrospective analysis was performed including 230 consecutive patients -who underwent cardiac surgery from September 2017 to January 2018 in a tertiary state hospital.

Results: There was significant difference between early extubated group and conventional group in the prevalence of comorbidities, duration of surgery, LOS in hospital and in the ICU. There was no significant difference between groups either in mechanical ventilation parameters including RSBI, mortality or morbidity.

Discussion and Conclusion: Early extubation offers a substantial advantage in terms of accelerated recovery, shorter intensive care unit, and hospital stay, suggesting that efforts to reduce extubation times are cost-effective. Early Extubation following cardiac surgery can be managed in a successful manner and comparing to conventional practices it saves valuable hours of patients. $\mathrm{RSBI}$, in the original cut-off point, was found useless as a weaning parameter while the threshold value for weaning failure was 31.

Keywords: Cardiac surgery; early extubation; rapid shallow breath index.
\end{abstract}

Özet

Amaç: Kardiyovasküler cerrahiyi takiben -postoperatif dönemde gece boyunca-ventilasyon 1960'dan beri rutin bir prosedürdü ve yüksek dozda opioid anestezi tekniklerinin kullanılması bu ihtiyacı pekiştiriyordu. Ancak bu hastaların erken dönemde ekstübasyonu, daha güvenli ve daha uygun maliyetli bir yaklaşım olarak öne sürülmüştür. Hızlı yüzeyel solunum indeksi (RSBI), Mekanik ventilatör desteğinden (MVS) ayırmayı standardize etmek ve bu girişimdeki başarısızlığı öngörmek için yaygın olarak kullanılmaktadır. Bu retrospektif çalışmanın amacı, kardiyovasküler cerrahi sonrası erken ekstübasyonun sonuçlar üzerine etkisini ve RSBI değerleri ile olası ilişkisini belirlemekti.

Gereç ve Yöntem: Bu retrospektif analiz, bir Üçüncü Basamak Devlet Hastanesinde Eylül 2017'den Ocak 2018'e kadar olan dönemde, kardiyak cerrahi geçirilen 230 ardışık hasta dahil edilerek yapıldı.

Bulgular: Erken ekstübasyon uygulanan grup ile konvansiyonel grup arasında komorbidite sıklığı, cerrahi süresi, hastanede ve YBÜ'de kalış süresinde anlamlı fark saptandı. RSBI gibi mekanik ventilasyon parametrelerinde, mortalite veya morbiditede gruplar arasında anlamlı fark saptanmadı.

Sonuç: Erken ekstübasyon hızlandırılmış iyileşme, daha kısa yoğun bakım ünitesi ve hastanede kalış süresi açısından önemli bir avantaj sunmaktadır. Bu da ekstübasyon zamanlarını azaltma çabalarının maliyet-etkin olduğunu düşündürmektedir. Kardiyak cerrahiyi takiben erken ekstübasyon başarılı bir şekilde yönetilebilir ve geleneksel uygulamalarla kıyaslandığında değerli hasta saatlerini korur. RSBI Orijinal eşik değeri olarak ele alındıgında MVS'den ayırma parametresi olarak yararsız bulunurken, bu çalışmada gözlenen cut-off değeri 31 olarak gözlendi. Anahtar Sözcükler: Kardiyak cerrahi; erken ekstübasyon; hızlı yüzeyel solunum indeksi

Corresponding (illetişim): Ibrahim Mungan, Ankara Eğitim ve Araştırma Şehir Hastanesi, Yoğun Bakım Ünitesi, Bilkent, Ankara, Turkey 
$\mathrm{O}$ vernight postoperative ventilation following cardiovascular surgery was a routine procedure since 1960 after the demonstration of frequent postoperative respiratory complications. The usage of high-dose opioid anesthetic techniques for cardiac surgery, strengthen the necessity of postoperative mechanical ventilation as in the classical approach. ${ }^{[1]}$ However, for about twenty years, this approach has been discussed in many studies. Early extubation, removal of endotracheal tube within 6 hours after the surgery, of postcardiac patients has been claimed as safer and more cost-effective approach. It is correlated with lower rates of respiratory complications and lower use of resources and becomes a common goal of postoperative recovery after cardiac surgery. ${ }^{[2,3]}$

Weaning from mechanical ventilatory support (MVS) continues to be an erroneous technique and dependent mainly on clinicians' experiences. Some parameters and calculated formulas like the ratio of respiratory frequency $(f)$ to tidal volume $(\mathrm{Vt})$ - also known as rapid shallow breath index (RSBI) - is used widely to standardize weaning from MVS and to predict failure of attempt. These formulas are utilized to convert weaning procedure from an art to a science..$^{[4,5]}$

There is another important point and it is that as clinicians try to hasten weaning, premature termination of mechanical ventilation risk emerges. And it is known that postcardiac patients are more susceptible to physiological stress and the damage to myocytes is devastating. ${ }^{[1]}$ Because of that, in the intensive care unit (ICU) proper management of these patients and mechanical ventilation issue remains to be an important clinical challenge. ${ }^{[6]}$ The aim of this retrospective study was to determine the impact of early extubation on post-cardiovasular surgery patients recovery, intensive care unit stay, and overall hospital stay and the possible correlations of RSBI values with early extubation and the outcomes.

\section{Materials and Method}

This retrospective analysis was performed including 230 consecutive patients -who underwent cardiac surgery from September 2017 to January 2018 in a tertiary state hospital. The procedures included were coronary artery bypass graft surgery, valvular replacement, thoracoabdominal aort aneurysm and dissections, and cardiomyopathy, comprising both urgent and emergent cases. Reoperated patients, individuals less than 18 years of age, patients with preoperative MVS need and off-pump surgeries were excluded from the study.

All patients underwent surgery by the same group of cardiac surgeons and standard anesthetic techniques were utilized. Patients were transferred to the ICU immediately after the operation and as a standardized procedure the lungs were ventilated using pressure-controlled ventilation, with goals of peak inspiratory pressure less than $30 \mathrm{~cm} \mathrm{H}_{2} \mathrm{O}, \mathrm{pH}$ 7.35-7.45, $\mathrm{pO}_{2}>80$ and $\mathrm{pCO}_{2}<50$. During the ICU process hemodynamic and neurological status as well as MVS parameters recorded in a hourly manner. As a routine procedure in our instution at first hours of the ICU course, patients were supported with pressure- Synchronized Intermittent Mandatory Ventilation (P-SIMV) and before extubation they were at spontaneous trials with Spontaneous Pressure Support mode or Continuous Positive Airway Pressure (CPAP) mode. In these modes, the pressure support was ranging from 8 to $16 \mathrm{~cm} \mathrm{H}_{2} \mathrm{O}$ with Positive End Expiratory Pressure varying from 3 to $6 \mathrm{~cm} \mathrm{H}_{2} \mathrm{O}$. All patients were weaned off the ventilator using a standard stepwise protocol and when they fulfilled standard criteriahemodynamic, respiratory and neurological parameters- they were extubated. ${ }^{[7]}$ The weaning decison had been given by clinicians and intensivists other than study contributors.

\section{Data Acquisition}

All clinical variables of patients were retrospectively collected from our institutional database. The patients were divided into two groups: Group A, those extubated in less than $6 \mathrm{~h}(\mathrm{n}=63)$ after arrival to ICU and Group B, those extubated in more than $6 \mathrm{~h}(\mathrm{n}=167)$. Both groups were analyzed on the following variables: surgery type, duration of surgery, medical history of the patients, preoperative ejection fraction, respiratory frequency, respiratory tidal volume, $\mathrm{RSBl}$, expired minute volume, postoperative complications (infections and mortality), weaning failure, need for tracheostomy, length of stay (LOS) in ICU and in hospital at all.

The extubation was considered a failure when patients needed reintubation within $48 \mathrm{~h}$ for any reason and in any case of prolonged mechanical ventilation need percutaneous dilatational tracheostomy procedure was performed. Blood stream infection is defined as (+) blood cultures post-operatively and respiratory infection is defined as (+) cultures of sputum, transtracheal fluid or transthoracic fluid; consistent clinical findings (including chest $x$-ray). Neurological complication is defined as transient ischemia, stroke, cerebrovasular accident or any motor dysfunction with (+) computerized tomography findings postoperatively continuing for greater than 72 hours. Mortality as a variable in this study was described as death from any cause occurring within 30 days after surgery.

\section{Statistical Analysis}

Statistical analysis was performed using SPSS version 20.0 for Windows (SPSS Inc., Chicago, IL, USA) and MedCalc 15.8 software (MedCalc, Ostend, Belgium). Data were analyzed, and the continuous variables were reported as mean \pm standard deviation (SD), and nominal variables were reported as total number and percentages.

Variables were first evaluated by One-Sample KolmogorovSmirnov test as a normality test to choose the type of statistical tests -parametric or non-parametric test-, and the results showed that asymp. Sig. (2-tailed) levels $\leq 0.05$ so we decided to use non-parametric tests. For statistical analysis, correlations between variables were evaluated for significance by using the Spearman's rho test. Categorical variables were evaluated by the Kruskal Wallis Test and Mann-Whitney $U$ test of contingency. In all analyses, a ' $p$ ' value less than 0.05 was con- 
Table 1. Demographic data and operational details of groups*

\begin{tabular}{lccc} 
& All (230) & Group A (n=63) & Group B (n=167) \\
\hline Age (years) & $56.83( \pm 12.93)$ & $54.56( \pm 14.81)$ & $57.69( \pm 12.08)$ \\
Gender (male) & $161(70 \%)$ & $48(76.2 \%)$ & $113(67.7 \%)$ \\
Operation type & & & 0.306 \\
$\quad$ Coronary bypass & $137(59.56 \%)$ & $34(53.96 \%)$ & $103(61.67 \%)$ \\
VR & $67(29.13 \%)$ & $23(36.5 \%)$ & $44(26.34 \%)$ \\
TAAA & $15(6.52 \%)$ & $4(6.34 \%)$ & $11(6.58 \%)$ \\
Cardiomyopathy & $11(4.78 \%)$ & $2(3.17 \%)$ & $9(5.38 \%)$ \\
Duration of surgery (minutes) & $313.77( \pm 96.18)$ & $292.3( \pm 104.38)$ & $321.86( \pm 91.93)$ \\
Medical history & $12(5.2 \%)$ & $1(1.6 \%)$ & $11(6.6 \%)$ \\
COPD & $10(4.3 \%)$ & $2(3.2 \%)$ & $8(4.8 \%)$ \\
Renal disease & $15(6.5 \%)$ & $2(3.2 \%)$ & $13(7.8 \%)$ \\
CHF & $8(3.5 \%)$ & $3(4.8 \%)$ & $5(3 \%)$ \\
DM & $52.61( \pm 10.09)$ & $52.19( \pm 10.52)$ & 0.032 \\
Preoperative EF & & $52.77( \pm 9.95)$ \\
\hline
\end{tabular}

*:Values are either expressed as mean \pm standard deviation or $n(\%) ;+: p$ values calculated for comparison of early versus conventional extubation group by statistical analysis. VR: Valvular replacement; TAAA: Thoraco abdominal aort aneurysm and dissections; COPD: Chronic obstructive pulmonary disease; CHF: Congestive heart failure; DM; Diabetus mellitus; EF: Ejection fraction.

Table 2. Postoperative outcomes with morbidity and mortality of groups*

\begin{tabular}{|c|c|c|c|c|}
\hline & All (230) & Group A $(n=63)$ & Group B $(n=167)$ & p value ${ }^{+}$ \\
\hline LOS in-hospital (days) & $7.5( \pm 5.31)$ & $6( \pm 1.75)$ & $8.07( \pm 6.05)$ & $<0.001$ \\
\hline LOS in- ICU (days) & $2.30( \pm 3.53)$ & $1.43( \pm 1.27)$ & $2.62( \pm 4.02)$ & 0.001 \\
\hline WF & $15(\% 6.5)$ & $3(4.8 \%)$ & $12(7.2 \%)$ & 0.508 \\
\hline Tracheostomy & $3(\% 1.4)$ & 0 & $3(1.8 \%)$ & 0.285 \\
\hline NC & $12(5.2 \%)$ & $3(4.8 \%)$ & $9(5.4 \%)$ & 0.849 \\
\hline In-hospital mortality & $8(3.5 \%)$ & $2(3.2 \%)$ & $6(3.6 \%)$ & 0.878 \\
\hline \multicolumn{5}{|l|}{ Infectious complications } \\
\hline Surgical site infections & $6(2.6 \%)$ & $3(4.8 \%)$ & $3(1.8 \%)$ & 0.996 \\
\hline Blood stream infections & $3(1.3 \%)$ & 0 & $3(1.8 \%)$ & \\
\hline Respiratory infections & $9(3.9 \%)$ & $2(3.2 \%)$ & $7(4.2 \%)$ & \\
\hline Surgical complications & $7(3 \%)$ & $2(3.17 \%)$ & $5(2.99 \%)$ & 0.86 \\
\hline
\end{tabular}

*: Values are expressed as either mean \pm standard deviation or $\mathrm{n}(\%) ;+: \mathrm{p}$ values calculated for comparison of early versus conventional extubation group by statistical analysis. LOS: Length of stay; NC: Neurological complications; WF: Weaning failure; ICU: Intensive care unit.

sidered statistically significant and comparisons were 2-tailed. The discrimination, which express the ability of the predictor of weaning success- like RSBI- according to the estimated failure was assessed using receiver operating characteristic (ROC) curves. The ROC curves were established as discrimination measurements with distributions per $10 \%$, according to the predicted failure and the obtained curve was appraised using the calculated area under the curve (AUC). AUC values $>0.75$ was appraised as satisfactory, AUC values $>0.8$ was appraised as well, and AUC values $>0.9$ was appraised as very good.

An extra formal consent other than the patients had given prior to hospitalization was not required for the current study because it was a case-control medical record review. Since our study was in the category of non-interventional clinical research with its retrospective structure, no ethics committee approval was applied.

This study adhered to the principles in accordance with the Helsinki declaration of 1975, as revised in 2008.

\section{Results}

The relationship of demographic data and operational details with early and conventional extubation groups is shown in Table 1. Patients in Group A were younger in contrast to patients in Group B but the difference was not significant statistically $(54,56$ versus 57,$69 ; p=0,306)$. There was significant difference between groups in the prevalence of congestive heart failure, diabetus mellitus, and respiratory illness $(p=0,023)$. With respect to preoperative cardiac parameters, Group A and 
Table 3. Extubation times and mechanical ventilation parameters of groups*

\begin{tabular}{|c|c|c|c|c|}
\hline & All (230) & Group A $(n=63)$ & Group B $(n=167)$ & p value ${ }^{+}$ \\
\hline Tidal volume & $499( \pm 79.23)$ & $484( \pm 79.39)$ & $504( \pm 78.72)$ & 0.063 \\
\hline $\begin{array}{l}\text { Extubation time } \\
\text { calculated }\end{array}$ & $9.04( \pm 5.28)$ & $5.44( \pm 0.77)$ & $10.4( \pm 5.62)$ & Not \\
\hline RSBI & $34.08( \pm 6.61)$ & $34.09( \pm 6.07)$ & $34.07( \pm 6.83)$ & 0.607 \\
\hline
\end{tabular}

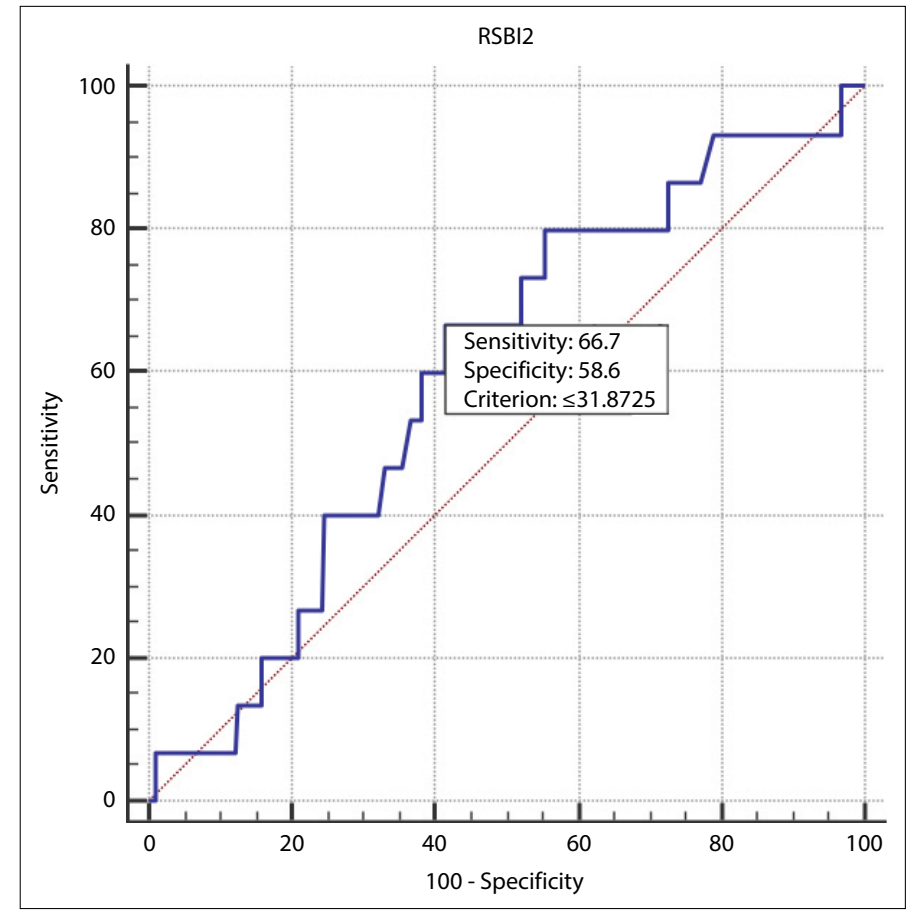

Figure 1. Receiver operating characteristic (ROC) curve of RSBI with low sensitivity and specificity. ROC: Receiver operating characteristic; RSBI: Rapid shallow breath index.

Group B had similar left ventricular ejection fraction (LVEF) $(52,19$ versus 52,77$)$. It is shown that not the type of surgery but the duration of surgery was found correlated with extubation time- between groups (292,3 min.versus 321,86 min.; $\mathrm{p}=0,032$ ).

Two deaths occurred among patients of Group $A$ and 6 deaths in group $B$ and in the view of mortality there was no statistical significant difference between groups. Patients postoperative outcomes with morbidity and mortality are listed in Table 2. There was no significant difference in the incidence of postoperative complications between groups. The ICU stay was shorter in Group A than in Group B, as shown in Table $2(1,43$ versus 2,62 days; $p=0,001$ ). Also, patients in Group $A$ were discharged from the hospital earlier than those in Group B, LOS in hospital was shorter ( 6 days versus 8,07 days; $p=<0,001$ ).

\section{Table 4. Area under the curve levels with RSBI}

\begin{tabular}{lc} 
Area under the ROC curve (AUC) & 0.599 \\
Standard error $^{\mathrm{a}}$ & 0.0720 \\
95\% Confidence interval $^{\mathrm{b}}$ & 0.532 to 0.663 \\
z statistic & 1.373 \\
Significance level P (Area=0.5) & 0.1699 \\
\hline ROC: Receiver operating characteristic: RSBI: Rapid shallow breath index.
\end{tabular}

In Table 3 it is shown that group A patients were extubated in $5,44 \mathrm{~h}( \pm 0,77)$, and group B patients were extubated in $10,4 \mathrm{~h}$ $( \pm 5,62)$, as expected. There were no significant difference between groups in mechanical ventilation parameters including $\mathrm{RSBI}$ and EMV greater than 10,1.

The discriminating power as the probability of weaning failure, assessed using the AUC, was not high enough with RSBI (AUC 0.599) while Youden index criterion was 31,87- too much lower than original cut- off value, 105- (Figure 1 and Table 4).

\section{Discussion}

Mechanical ventilatory support during postsurgical period asists clinician not only by improving oxygenation but also by reducing preload after cardiac surgery. ${ }^{[1]}$ Because of that, some cardiovasular clinics choose conventional or late extubation whereas some prefers early extubation as a method. Improvements in ICU practice, as well as in surgery and anesthesia, have evolved previous conventional approaches to fast-track recovery and early extubation following cardiac surgery is an important part of this..$^{[7]}$ Nevertheless early extubation time changes in different studies and there is no exact description of it. Mostly in the literature 6 hours is described as a cut-off point and in this study it is defined as endotracheal tube removal within $6 \mathrm{~h}$ of ICU admission. ${ }^{[8]}$

Early extubation is claimed to be advantegous over conventional method but risk of premature weaning is still intimidating like Damocles sword. ${ }^{[9]}$ Besides that there is no validated criteria in a prospective manner style. Some mechanical ventilatory parameters and formulas like RSBI $<105$ are proposed to estimate successful weaning as it is considered to be important to detect the failure in the extubation process. ${ }^{[10]}$ Yet it 
is known that cardiovasular diseases and older age may make prediction power less accurate. ${ }^{[5,11]}$ In our study groups, mean ages were similar and it was 56,83 years in whole population. Mean RSBI value is 34 - even not close to cut-off value of 105 that was proposed as a weaning failure predictor by Yang and Tobin ${ }^{[12]}$ - and no statistical difference between groups were detected. It is consistent with latter studies that showed smaller threshold for RSBI. ${ }^{[13]}$ Our findings showed that even in lower cut-off values, like 31,RSBI has poor predictive power of weaning failure in the postcardiac patients.

In previous studies it is shown that intraoperative factors do not have an important role in early extubation so in our study we did not analyse intraoperative factors. ${ }^{[14]}$

Both delayed and premature extubation have been associated with adverse outcomes. Besides that, decreased morbidity rates, increased cardiac efficiency with less noscomial pneumonia and atelectesia rates are advantages of early extubation as it is discussed in some studies. In these studies it is claimed that early extubation expedites the return of ciliary function and this recovers respiratory functions earlier than conventional approach so less nosomial pneumonia risk occurs. ${ }^{[15]}$ We could not find any statistical difference between groups according to morbidity and mortality so we can conclude that early extubation has no relation with increased morbidity and mortality as well. Besides that LOS in hospital and in ICU was reduced in early extubation group and difference was significant statistically, thus decreasing cost in the postoperative period became a major advantage as it is emphasized in recent studies. ${ }^{[9,11]}$

Although this study was designed in a retrospective manner, special precautions were taken in study process to avoid bias. In our study contributors /authors had no affect on extubation time, postcardiotomy patients were weaned from mechanical ventilation when they were awake, warm, hemodynamically stable, oxygenated and ventilated adequately. The weaning decision was done by the clinicians and intensivists other than authors. Nevertheless one should admit that without randomized prospective trials it is hard to make inferences about safety and utility of early extubation in postcardiotomy patients. But we also thought that this does not embower the beneficial role of early extubation.

Early extubation offers a substantial advantage in terms of accelerated recovery, shorter intensive care unit, and hospital stay, suggesting that efforts to reduce extubation times are cost-effective. ${ }^{[1,16]}$ This benefit can be achieved through either lowering the intensity of intraoperative anesthesia, decreasing postoperative sedation, or instituting a policy of early extubation without other specific interventions. In a meta analysis, in which early extubation was compared to conventional extubation by using five trials' data, only reduction of anesthetic doses intraoperatively has been correlated with shortened mechanical ventilatory support and the other outcomes were not different in early extubation group. ${ }^{[17]}$ This meta analysis is important in means of safety of the early extubation.

\section{Conclusion}

Early Extubation following cardiac surgery can be managed in a successful manner and comparing to conventional practices it saves valuable hours of patients. Our study findings show that early extubated patients spend less time in the ICU and the hospital consistent with previously published data. RSBI is valuable only in cutoff point 31 , and that is lower than original cutoff point which was 105 with low sensitivity and specifity.

\section{Limitations}

Limitations of this study include all those inherent to any retrospective single-institution analysis. All data elements, however, were collected from instutional database with strict definitions. Additionally, unvalued for confusing parameters could have affected the results and the low median time of endotracheal intubation with small number of patients could overshadow the relations. But this study demonstrates the undeniable benefits of early extubation in cardiovascular surgery.

Authorship statement: All authors had full access to the data and participated in the data collection, design and writing of the manuscript. Each author has seen and approved the submitted version.

Conflict of interest: There are no relevant conflicts of interest to disclose.

Funding: This study was not financially supported.

\section{References}

1. Rashid A, Sattar KA, Dar MI, Khan AB. Analyzing the outcome of early versus prolonged extubation following cardiac surgery. Ann Thorac Cardiovasc Surg. 2008;14(4):218-23

2. Zayat R, Menon AK, Goetzenich A, et al. Benefits of ultra-fasttrack anesthesia in left ventricular assist device implantation: a retrospective, propensity score matched cohort study of a fouryear single center experience. Journal of Cardiothoracic Surgery. 2017;12:10. doi:10.1186/s13019-017-0573-9

3. Camp SL, Stamou SC, Stiegel RM, et al. Can timing of tracheal extubation predict improved outcomes after cardiac surgery? HSR Proceedings in Intensive Care \& Cardiovascular Anesthesia. 2009;1(2):39-47.

4. Huaringa AJ, Wang A, Haro MH, Leyva FJ. The weaning index as predictor of weaning success. J Intensive Care Med. 2013 NovDec;28(6):369-74. doi: 10.1177/0885066612463681.

5. Jeganathan N, Kaplan CA, Balk RA. Ventilator Liberation for HighRisk-for-Failure Patients: Improving Value of the Spontaneous Breathing Trial.Respir Care. 2015 Feb;60(2):290-6. doi: 10.4187/ respcare.03111.

6. Siner JM, Connors GR. Protocol-based care versus individualized management of patients in the intensive care unit. Semin Respir Crit Care Med 2015;36(6):870.877.

7. Chan JL, Miller JG, Murphy M,et al. A Multidisciplinary ProtocolDriven Approach to Improve Extubation Times Following Cardiac Surgery. Ann Thorac Surg. 2018 Mar 9. pii: S0003-4975(18)303199. doi: 10.1016/j.athoracsur.2018.02.008. [Epub ahead of print] 
8. Wong WT, Lai VK, Chee YE, Lee A. Fast-track cardiac care for adult cardiac surgical patients. Cochrane Database Syst Rev 2016;9:CD003587.

9. Cove ME, Ying C, Taculod JM et al. Multidisciplinary extubation protocol in cardiac surgical patients reduces ventilation time and length of stay in the intensive care unit. Ann Thorac Surg 2016;102(1):28.34.

10. Karthika M, Al Enezi FA, Pillai LV, Arabi YM. Rapid shallow breathing index. Annals of Thoracic Medicine. 2016;11(3):167-176. doi:10.4103/1817-1737.176876.

11. Cheikhrouhou $H$, Kharrat A, Derbel R, et al. L'effet de l'extubation precoce apres chirurgie cardiaque pour la rehabilitation post opératoire. The Pan African Medical Journal. 2017;28:81. doi:10.11604/pamj.2017.28.81.11432.

12. Yang $\mathrm{KL}$, Tobin MJ. A prospective study of indexes predicting the outcome of trials of weaning from mechanical ventilation. $\mathrm{N}$ Engl J Med 1991;324:1445-50.
13. Juern JS. Removing the critically ill patient from mechanical ventilation. Surg Clin North Am. 2012;92(6):1475-83.

14. Engoren $M$, Buderer NF, Zacharias $A$, et al. Variables predicting reintubation after cardiac surgical procedures. Ann Thorac Surg 1999;67(3):661-5.

15. Akhtar Ml, Sharif $H$, Hamid $M$, et al. Fast Track Extubation In Adult Patients On Pump Open Heart Surgery At A Tertiary Care Hospital. J Ayub Med Coll Abbottabad. 2016 OctDec;28(4):639-643.

16. David RA, Brooke BS, Hanson KT, et al. Early extubation is associated with reduced length of stay and improved outcomes after elective aortic surgery in the Vascular Quality Initiative. J Vasc Surg. 2017 Jul;66(1):79-94.e14. doi: 10.1016/j.jvs.2016.12.122. Epub 2017 Mar 31.

17. Meade MO, Guyatt G, Butler R, et al. Trials comparing early vs. late extubation following cardiovascular surgery. Chest 2001;120:445S-53S. 